\title{
GROWTH, YIELD AND YIELD ATTRIBUTES OF SUMMER GREEN GRAM (VIGNA RADIATA L.WILEZECK) UNDER MEDIUM BLACK CALCAREOUS SOILS AS INFLUENCED BY APPLICATION OF SULPHUR AND ZINC LEVELS
}

\author{
DHARMIK SOLANKI, PAMU SWETHA \& M. S. SOLANKI \\ Department of Agricultural Chemistry and Soil Science College of Agriculture, \\ Junagadh Agricultural University, Junagadh, Gujarat, India
}

\begin{abstract}
A field experiment was conducted at the Instructional Farm, College of Agriculture, Junagadh Agricultural University, Junagadh during summer season of 2014, to assess the response of summer green gram (Vigna radiata $L$. Wilezeck) to four levels of sulphur viz., 0, 10, 20 and $30 \mathrm{~kg} \mathrm{~S} \mathrm{ha}{ }^{-1}$, and three levels of Zinc viz., 0, 2.5 and $5.0 \mathrm{~kg} \mathrm{Zn} \mathrm{ha}^{-1}$. The results of different sulphur and zinc levels depicted that application of $30 \mathrm{~kg} \mathrm{~S} \mathrm{ha}^{-1}$ and $5.0 \mathrm{~kg} \mathrm{Zn} \mathrm{ha-1}$ significantly increased the plant height, number of branches per plant, number of pods plants, number of seeds per pod, number of root nodules per plant, seed and straw yield. Sulpur also increased the dry weight of root nodules, 100 seed weight. The interaction effect of sulpur and zinc and produced the significant results on seed and straw yield.
\end{abstract}

KEYWORDS: Summer Green Gram, Sulphur Levels, Zinc Levels, Growth Parameters, Yield \& Yield Attributes

Received: Jul 03, 2017; Accepted: Jul 27, 2017; Published: Aug 07, 2017; Paper Id.: IJASRAUG201786

\section{INTRODUCTION}

Mung bean (Vigna radiata L. Wilezeck) is one of the important pulse crops of India. Green gram (Vigna radiata L.), commonly known as "Mung" or "Mungbean" is one of the most important pulse crops in India, ranking fourth in respect of cultivated area. India alone accounts for 65 per cent of its world acreage and 54 per cent of the production. Sulphur, an essential secondary plant nutrient, is required by plant and animals in approximately the same amount as phosphorus. On an average, the amount of sulphur content in the earth crust is ranged about 0.06 to 0.10 per cent. Pulses are particularly responsive to sulphur containing fertilizers, and that elementary sulphur or sulphates increases the percentage of nitrogen as well as yield on such deficient soils. Zinc useful in production of growth hormones, elongation of the nodes and in the chloroplast and starch grain is effective. Spraying micronutrient is beneficial for the growth of green grams and its quality (Khorgami and Farnia, 2006).

The Saurashtra region of Gujarat is being highly influenced by the vagaries of monsoon, which results in low and unstable crop yields. The region faces twin problems of poor fertility and inadequate moisture availability for crop production that results in partial or total failure of crop, with occurrence of mild to severe drought. At the same time, management of sulphur and zinc is must to achieve potential green gram production.

\section{MATERIAL AND METHODS}

The experiment was conducted during rabi, season 2013-14 in D-5 plot of Instructional Farm at Krushigadh College of Agriculture, Junagadh Agricultural University, Junagadh. The experiments were laid out in Factorial Randomized Block Design having 12 treatments with three replications. The experiment consisted of 4 
levels of sulphur $\left(0,10,20\right.$ and $\left.30 \mathrm{~kg} \mathrm{~S} \mathrm{ha}^{-1}\right)$ and 3 levels of zinc $\left(0,2.5,5 \mathrm{~kg} \mathrm{Sha}^{-1}\right)$.

The soil of the experimental field was medium black calcareous soil with $\mathrm{pH} 8.0$ and EC $0.57 \mathrm{dS} \mathrm{m}^{-1}$. The crop was fertilized with sulphur and zinc as per treatment allotted to each plot in the form of Cosavet fertis, WG (90\%) and $\mathrm{ZnO}$ in basal application. Green gram, GM- 4 variety was used as planting material in this study. The seeds were dibbled at a spacing of $30 \times 10 \mathrm{~cm}$ using a seed rate of $20 \mathrm{~kg} \mathrm{ha}^{-1}$ during the first week of February.

Five plants were selected at random from each plot to record individual plant nutrient content and uptake by some analyses in the leaves, shoot, root and seed. The soil analysis was carried out according to standard methods. The soil used in the experiment was clayey in texture, containing 35.16, 2.97 and $61.87 \%$ sand, silt and clay, respectively. The pH, EC $\left(25^{\circ} \mathrm{C}\right)$ and available N, P, K, S and Zn were 8.0, $0.57 \mathrm{dS} \mathrm{m}^{-1}$ and $207.30 \mathrm{~kg} \mathrm{ha}^{-1}, 36.80 \mathrm{~kg} \mathrm{ha}^{-1}, 185.70 \mathrm{~kg} \mathrm{ha}^{-1}, 14.38 \mathrm{~kg}$ $\mathrm{ha}^{-1}$ and $0.77 \mathrm{~kg} \mathrm{ha}^{-1}$ respectively. In general, the experimental soil was medium in $\mathrm{N}$ as well as $\mathrm{K}$ and low in $\mathrm{P}$ and $\mathrm{S}$.

\section{RESULTS AND DISCUSSIONS}

\section{Effect of Sulphur}

Application of sulphur produced significant effect on yield attributes (Table 1) viz., plant height, number of branches per plant, number of pod per plant, number of seeds per pod and test weight of green gram. Significantly, the higher values of these attributes were recorded under $30 \mathrm{~kg} \mathrm{Sha}^{-1}\left(\mathrm{~S}_{3}\right)$ as compared to those of control $\left(\mathrm{S}_{0}\right)$ and $10 \mathrm{~kg} \mathrm{Sha}^{-1}$ $\left(\mathrm{S}_{1}\right)$; however, generally, they were at par with $20 \mathrm{~kg} \mathrm{~S} \mathrm{ha}^{-1}\left(\mathrm{~S}_{2}\right)$. The values registered for these parameters from control $\left(\mathrm{S}_{0}\right)$ and $10 \mathrm{~kg} \mathrm{Sha}^{-1}\left(\mathrm{~S}_{1}\right)$ were generally at par with each other. The beneficial effect of application of sulphur on growth and yield attributes might be due to the fact that sulphur application improved over all nutritional environment of the Rhizosphere as well as plant system, which could be more advantageous for profuse vegetative and root growth which activate higher absorption of nutrients from the soil. Increase in growth and yield can be ascribed to cell division, enlargement and elongation resulting in overall improvement in plant organs associated with faster and uniform growth of plant under sulphur application. All these had resulted into higher yield attributes. The results confirmed to reports of Salvi et al. (1992) and Jat and Rathore (1994) in green gram, Ravichandran et al. (1995) in blackgram, Shekhawat et al. (1996), Shivram et al. (1996), Bhadoria et al. (1997), Kumawat and Khangarot (2002) in clusterbean and Singh et al. (2004) in chickpea.

The number of root nodules and its dry weight per plant were significantly affected due to application of sulphur, which were recorded significantly higher under sulphur level $\mathrm{S}_{3}\left(30 \mathrm{~kg} \mathrm{~S} \mathrm{ha}^{-1}\right)$, but statistically at par with that of $20 \mathrm{~kg} \mathrm{~S}$ $\mathrm{ha}^{-1}\left(\mathrm{~S}_{2}\right)$. The non-significant difference in number of root nodules and dry weight of root nodules per plant was found between control $\left(\mathrm{S}_{0}\right)$ and $10 \mathrm{~kg} \mathrm{~S} \mathrm{ha}^{-1}\left(\mathrm{~S}_{1}\right)$. The increase in number of root nodules and dry weight of nodules per plant could be attributed to its pivotal role in regulating the metabolic and enzymatic processes including photosynthesis and respiration. Due to good Rhizosphere, more activities of micro-organism in soil, so increase in number of nodules plant ${ }^{-1}$. The results are in line of the results of those reported by Singh et al. (2004) in chickpea.

Seed and straw yield of green gram was significantly increased with increasing levels of sulphur, wherein, seed and straw yield recorded due to application of sulphur @ $30 \mathrm{~kg} \mathrm{Sha}^{-1}\left(\mathrm{~S}_{3}\right)$ was significantly higher as compared to control $\left(\mathrm{S}_{0}\right)$ and $10 \mathrm{~kg} \mathrm{~S} \mathrm{ha}^{-1}\left(\mathrm{~S}_{1}\right)$. Sulphur is an essential element which increases root growth, promote nodules formation and stimulates seed formation ultimately resulting into better growth and development of the crop plants, which might have increased the values of growth and yield attributes viz., plant height, number of pods per plant, number of seeds per pod 
and test weight, which had combined effects on seed and straw yield. The results are in close agreement with the findings of Jat and Rathore (1994) and Singh and Yadav (2000) in green gram, Ravichandran et al. (1995) in blackgram, Shekhawat et al. (1996), Shivram et al. (1996), Bhadoria et al. (1997), Kumawat and Khangarot (2002) in clusterbean, Sepat and Yadav (2008) in mothbean and Gurjar (2012) in soybean.

\section{Effect of Zinc}

Application of zinc produced significant effect (Table 1) on plant height, number of branches per plant, number of pods per plant and number of seeds per plant. The values for these parameters noticed due to application of $5.0 \mathrm{~kg} \mathrm{Zn} \mathrm{ha}^{-1}$ $\left(\mathrm{Zn}_{2}\right)$ was significantly higher than control $\left(\mathrm{Zn}_{0}\right)$ and $2.5 \mathrm{~kg} \mathrm{Zn} \mathrm{ha}^{-1}\left(\mathrm{Zn}_{1}\right)$. This might be due to the fact that zinc application improved over all nutritional environments of plant, which improves the growth and development of plant. It plays role in initiation of primordial for reproductive parts and partitioning in of photosynthesis towards them, resulted in better flowering and fruiting. Similar results were reported by Singh and Singh (1995) in soybean, Kalyanaraman and Sivagurunath (1993) in green gram, and Meena et al. (2001) in clusterbean

The dry weight of root nodules per plant did not reach to the level of significance due to different rates of zinc application but, the number of root nodules per plant was significantly affected due to zinc levels. Significantly, the highest number of root nodules per plant was observed with the application of $5.0 \mathrm{~kg} \mathrm{Zn} \mathrm{ha}{ }^{-1}\left(\mathrm{Zn}_{2}\right)$ as compared to control $\left(\mathrm{Zn}_{0}\right)$ and $2.5 \mathrm{~kg} \mathrm{Zn} \mathrm{ha}^{-1}\left(\mathrm{Zn}_{1}\right)$. The increase in number of root nodules per plant could be attributed to its pivotal role of zinc in regulating the metabolic and enzymatic processes, including photosynthesis and respiration. Balance nutrition provides good Rhizosphere around roots, so increase in number of nodules plant ${ }^{-1}$. Quah et al. (1996) reported the similar results in green gram, Kushwah (1993) in urdbean and Meena et al. (2001) in clusterbean.

The seed and straw yield of green gram was significantly increased with increasing levels of zinc, wherein, significantly the highest seed and straw yield was registered under the application of $5.0 \mathrm{~kg} \mathrm{Zn} \mathrm{ha}{ }^{-1}\left(\mathrm{Zn}_{2}\right)$. Zinc is an essential element, which increases root growth, promote root nodulation and stimulates seed formation ultimately resulting into better growth and development of the crop plants. Zinc also play vital role in metabolic activities in plant system. Kalyanaraman and Sivagurunath (1993), Quah et al. (2004) in green gram, Khorgamy and Farnia (2006) in chickpea and Sharma et al. (2004) in cluster bean reported similar results.

\section{Interaction Effect}

The $\mathrm{S} \times \mathrm{Zn}$ interaction was found non-significant on growth and yield attributes (Table 2), but it was found significant on seed and straw yield of green gram (Figure 1 and 2). Treatment combination of $30 \mathrm{~kg} \mathrm{~S}$ and $5.0 \mathrm{~kg} \mathrm{Zn} \mathrm{ha}{ }^{-1}$ $\left(\mathrm{S}_{3} \mathrm{Zn}_{2}\right)$ recorded significantly the highest seed $\left(1162 \mathrm{~kg} \mathrm{ha}^{-1}\right)$ and straw $\left(2064 \mathrm{~kg} \mathrm{ha}^{-1}\right)$ yield, whereas control of both the factors $\left(\mathrm{S}_{0} \mathrm{Zn}_{0}\right)$ recorded the minimum seed $\left(791 \mathrm{~kg} \mathrm{ha}^{-1}\right)$ and straw $\left(1473 \mathrm{~kg} \mathrm{ha}^{-1}\right)$ indicating synergistic effect of $\mathrm{S}$ and $\mathrm{Zn}$ on crop yield. Similar results were also reported by Krishna (1995), Srivastav et al. (2006) and Ram and Katiyar (2013) in green gram. 
Table 1 Effect of Sulphur and Zinc on Growth, Yield and Yield Parameters of Popcorn

\begin{tabular}{|c|c|c|c|c|c|c|c|c|c|}
\hline \multirow[b]{2}{*}{ Treatments } & \multirow{2}{*}{$\begin{array}{c}\text { Plant Height } \\
\text { (cm) }\end{array}$} & \multirow{2}{*}{$\begin{array}{c}\text { Number of } \\
\text { Branches } \\
\text { Plant }^{-1}\end{array}$} & \multirow{2}{*}{$\begin{array}{l}\text { Number of } \\
\text { Pods Plant }{ }^{-1}\end{array}$} & \multirow{2}{*}{$\begin{array}{l}\text { Number of } \\
\text { Seeds Pods }{ }^{-1}\end{array}$} & \multirow{2}{*}{$\begin{array}{l}\text { Number of Root } \\
\text { Nodules Plant }{ }^{-1}\end{array}$} & \multirow{2}{*}{$\begin{array}{l}\text { Dry Weight of } \\
\text { Root Nodules } \\
\text { (mg Plant }^{-1} \text { ) }\end{array}$} & \multirow{2}{*}{$\begin{array}{c}\text { Test } \\
\text { Weight (g) }\end{array}$} & \multicolumn{2}{|c|}{ Yield $\left(\mathrm{kg} \mathrm{ha}^{-1}\right)$} \\
\hline & & & & & & & & Seed & Straw \\
\hline \multicolumn{10}{|c|}{ Levels of Sulphur $\left(\mathrm{kg} \mathrm{ha}^{-1}\right)$} \\
\hline $\mathrm{S}_{0}: 00$ & 39.38 & 10.01 & 17.40 & 10.57 & 27.21 & 35.36 & 34.53 & 895 & 1674 \\
\hline $\mathrm{S}_{1}: 10$ & 41.65 & 11.07 & 17.54 & 10.49 & 28.07 & 36.98 & 35.16 & 932 & 1770 \\
\hline $\mathrm{S}_{2}: 20$ & 43.52 & 11.24 & 19.69 & 11.30 & 29.77 & 38.43 & 35.89 & 964 & 1892 \\
\hline $\mathrm{S}_{3}: 30$ & 46.52 & 12.28 & 19.73 & 11.67 & 30.69 & 40.18 & 36.47 & 1086 & 1934 \\
\hline S.Em. \pm & 1.28 & 0.29 & 0.56 & 0.25 & 0.80 & 0.92 & 0.35 & 25 & 29 \\
\hline $\mathrm{CD}(\mathrm{P}=0.05)$ & 3.77 & 0.84 & 1.64 & 0.74 & 2.33 & 2.69 & 1.02 & 72 & 84 \\
\hline \multicolumn{10}{|c|}{ Levels of zinc $\left(\mathrm{kg} \mathrm{ha}^{-1}\right)$} \\
\hline $\mathrm{Zn}_{0}: 0$ & 40.97 & 10.68 & 16.92 & 10.50 & 27.50 & 37.28 & 35.15 & 910 & 1712 \\
\hline $\mathrm{Zn}_{1}: 2.5$ & 42.28 & 11.16 & 18.78 & 10.69 & 28.79 & 37.78 & 35.46 & 974 & 1829 \\
\hline $\mathrm{Zn}_{2}: 5.0$ & 45.06 & 11.61 & 20.06 & 11.84 & 30.51 & 38.15 & 35.93 & 1023 & 1911 \\
\hline S. Em. \pm & 1.11 & 0.25 & 0.48 & 0.22 & 0.69 & 0.79 & 0.30 & 21 & 25 \\
\hline $\mathrm{CD}(\mathrm{P}=0.05)$ & 3.26 & 0.73 & 1.42 & 0.64 & 2.02 & NS & NS & 62 & 72 \\
\hline $\mathbf{S} \times \mathbf{Z n}$ Interaction & NS & NS & NS & NS & NS & NS & $\mathrm{NS}$ & Sig. & Sig. \\
\hline CV\% & 9.01 & 7.74 & 9.01 & 6.86 & 8.25 & 7.29 & 2.95 & 8.0 & 5.0 \\
\hline
\end{tabular}

Table 2: Interaction Effect of S and Zn Seed and Straw Yield

\begin{tabular}{|c|c|c|c|c|}
\hline \multirow{2}{*}{ Level of Zinc } & \multicolumn{4}{|c|}{ Level of Sulphur } \\
\hline & $\mathbf{S}_{\mathbf{0}}$ & $S_{1}$ & $\mathbf{S}_{2}$ & $\mathbf{S}_{3}$ \\
\hline \multicolumn{5}{|c|}{ Seed Yield $\left(\mathrm{kg} \mathrm{ha}^{-1}\right)$} \\
\hline $\mathbf{Z n}_{\mathbf{0}}$ & 917 & 791 & 933 & 998 \\
\hline $\mathbf{Z n}_{1}$ & 899 & 947 & 954 & 1098 \\
\hline $\mathbf{Z n}_{2}$ & 868 & 1059 & 1004 & 1162 \\
\hline S. Em. \pm & \multicolumn{4}{|c|}{43} \\
\hline $\mathrm{CD}(\mathrm{P}=\mathbf{0 . 0 5})$ & \multicolumn{4}{|c|}{125} \\
\hline C.V.\% & \multicolumn{4}{|c|}{8.0} \\
\hline \multicolumn{5}{|c|}{ Straw Yield $\left(\mathrm{kg} \mathrm{ha}^{-1}\right)$} \\
\hline $\mathbf{Z n}_{0}$ & 1473 & 1747 & 1844 & 1784 \\
\hline $\mathbf{Z n}_{1}$ & 1742 & 1779 & 1840 & 1953 \\
\hline $\mathbf{Z n}_{2}$ & 1806 & 1783 & 1991 & 2064 \\
\hline S. Em. \pm & \multicolumn{4}{|c|}{49} \\
\hline $\mathrm{CD}(\mathrm{P}=0.05)$ & \multicolumn{4}{|c|}{145} \\
\hline C.V.\% & \multicolumn{4}{|c|}{5.0} \\
\hline
\end{tabular}




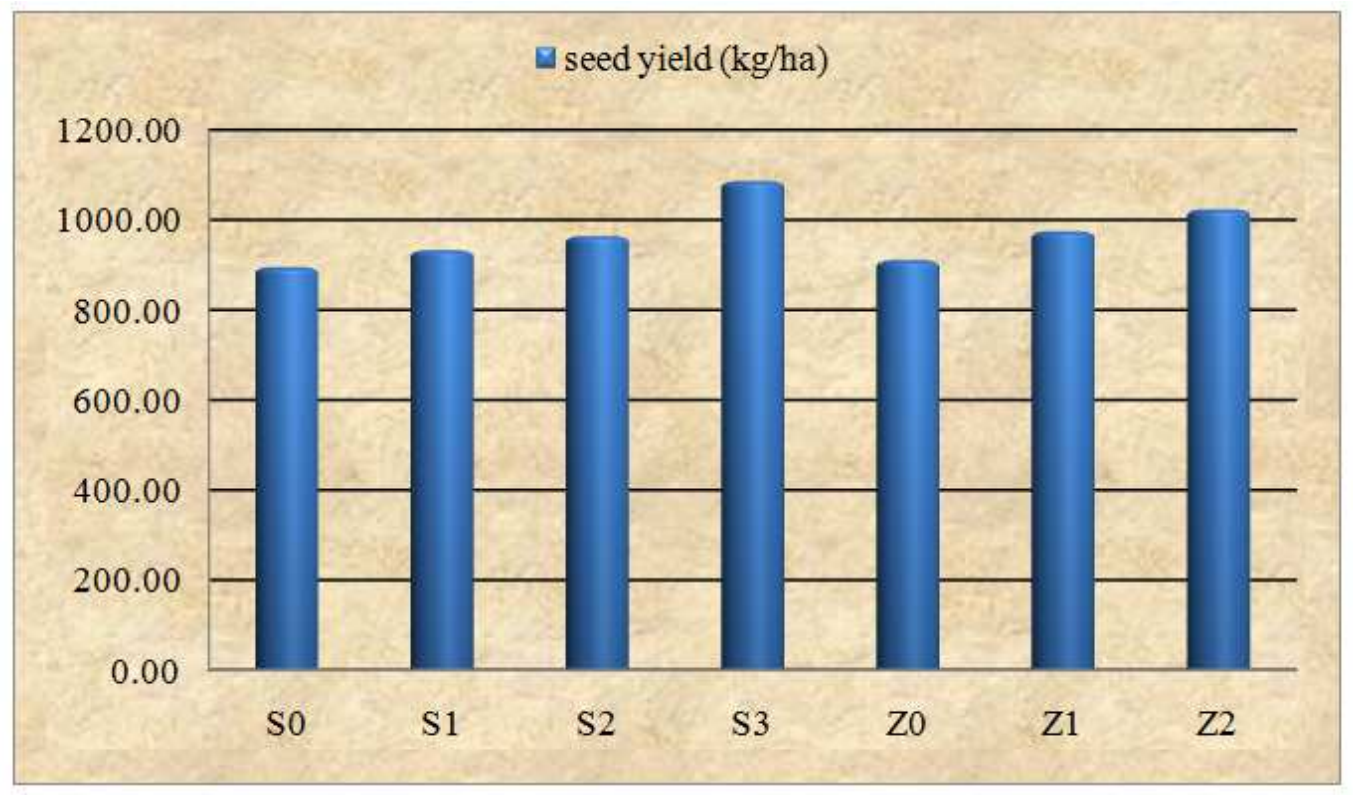

Figure 1: Effect of Sulphur and Zinc on Seed Yield $\left(\mathrm{kg} \mathrm{ha}^{-1}\right)$

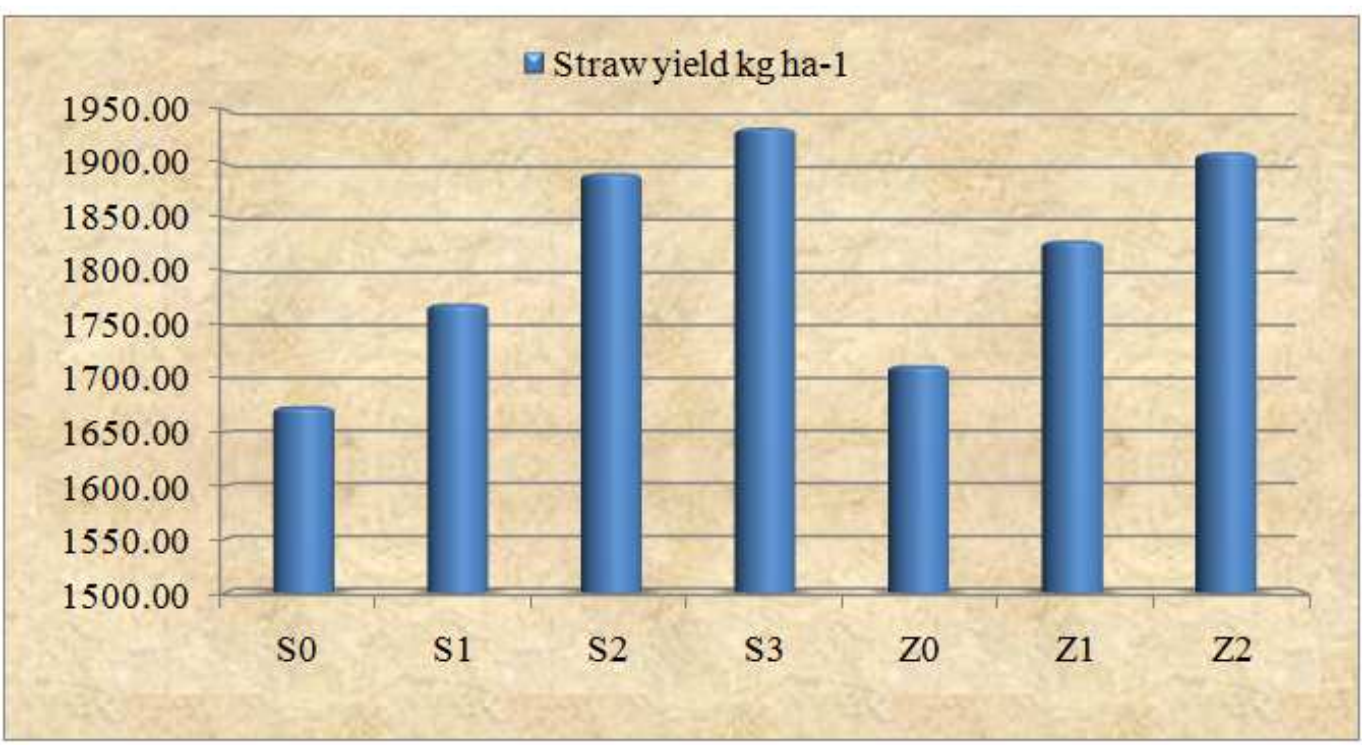

Figure 2: Effect of Sulphur and Zinc on Straw Yield $\left(\mathrm{kg} \mathrm{ha}^{-1}\right)$

\section{REFERENCES}

1. Bhadoria, R. B. S.; Tomar, R. A. S.; Khan, H. and Sharma, M. K.1997. Effect of phosphorus and sulphur on yield and quality of cluster bean (Cyamopsis tetragonoloba (L.) Taub.) Indian Journal of Agronomy, 42 (1): 131-134.

2. Gurjar, R. 2012. Effect of phosphorus and sulphur on yield and quality of soybean (Glycine max L.) grown on Typic Ustochrept of Anand. M.Sc. thesis submitted to Dept. of Agril. Chem. and Soil Science, B.A.C.A., Anand Agriculture University, Anand, (Gujarat).

3. Jat, R. L. and Rathore, P. S. 1994. Effect of sulphur, molybdenum and Rhizobium inoculation on green gram. Indian Journal of Agronomy, 39(4):651-654.

4. Kalyanaraman, A. and Sivagurunath, P.1993. Studied the effect of cadmium, copper and zinc on the green gram. Journal Of Plant Nutrition, 16(10): 2029-42. 
5. Khorgami, A. and Farnia, A. 2006. Effect of phosphorus and zinc fertilization on yield and yield components of chick pea cultivars. African Crop Science Conference Proceedings, 9: 205-208.

6. Khuswah, B. L. 1993. Response of Urdbean to phosphorus and zinc application. Indian Journal of Pulses Research., 6 (2) : 152-154.

7. Krishna 1995. Effect of sulphur and zinc application on yield, S and Zn uptake and protein content of mung (green gram). Legume Research, 18 (2): 89-92.

8. Kumawat, P. D. and Khangarot, S. S. 2002. Response of sulphur, phosphorus and Rhizobium inoculation on content and uptake of nutrients of cluster bean (Cyamopsis tetragonoloba (L.) Taub.). Environmental Ecology, 20 (4): 803-805.

9. Meena, K. R.; Dahama, A. K. and Reager, M. L. 2006. Effect of phosphorus and zinc fertilization on growth and quality of clusterbean (Cyamopsistetragonoloba.L. Taub). Journal of annals of Agricultural Research.27 (3): 224-226.

10. Ram, S. and Katiyar, T. P. S. 2013. Effect of sulphur and zinc on the seed yield and protein content of summer mungbean under arid climate, Internat. Journal. Of Science. and Nature., 4(3): 563-566.

11. Ravichandran, V. K.; Singravelu, P. and Balasubramaniam, N. 1995. Effect of sources and levels of sulphur application on yield and economics of blackgram. Madras Agriculture Journal , 82(3): 224-225.

12. Salvi, N. N.; Patel, L. R. and Patel, R. H. (1992). Response of green gram (Phaseolus radiates) varities of sulphur fertilization under different levels of nitrogen and phosphorus. Indian Journal of Agronomy, 37(4): 831-833.

13. Sepat, S. and Yadav, S. S. 2008. Phosphorus and Sulphur management in moth bean (Vigna aconitifolia) under rainfed condition. Annals of Agricultural Research, New Series, 29(1, 2, 3 \& 4): 38-42.

14. Sharma K.; Jain, K. K. and Sharma, S. K. 2004. Yield component of clusterbean as influenced by zinc and thiourea. Journal of annals of Agricultural Research.25 (1): 169-171.

15. Shekhawat, P. S.; Rathore, A. S. and Mansingh 1996. Effect of source and levels of sulphur on yield attributes and seed yield of clusterbean (Cyamopsis tetragonoloba) under rainfed condition. Indian Journal of Agronomy, 41(3):424-426.

16. Shivram, A. C.; Khangarot, S. S.; Shivran, P. L. and Gora, D. R. (1996). Response of cluster bean (Cyamopsis tetragonoloba (L.) Taub.) varieties to sulphur and phosphorus. Indian Journal of Agronomy, 41(2): 340-342.

17. Singh, S.; Saini, S. S. and Singh, B. P. 2004. Effect of irrigation, sulphur and seed inoculation on growth, yield and sulphur uptake of chickpea (cicer arietinum) under late-sown conditions. Indian Journal of Agronomy, 49(1): 57-59.

18. Singh, U. and Yadav, D. S. 2000. Economics of summer green gram (Phaseolus radiates L.) cultivation as influenced by sulphur and zinc levels. Legume Research, 23(1):67-68.

19. Singh, D. and Singh, V. 1995. Effect of K, Zn and S on growth characters, yield attributes and yield of soybean (Glycine max). Indian Journal of Agronomy. 40 (2): 223-227.

20. Srivastava, A. K.; Tripathi, P. N.; Singh, A. K. and Singh, R. 2006. Effect of rhizobium, sulphur and zinc levels on growth, yield, nutrient uptake and quality of summer green gram (Phaseolus radiatus L.). International Journal of Agriculture Science, $2(1): 190-192$.

21. Quah, S. C.; Hashim, N. F.; Kusnan, M. and Bujang, I. 2004. Effect of Zinc on nodulation in mung bean Second National Congress on Genetics, 13-15 November 1996, Genetic Society of Malasiya. 